BNL 853 (I-339)

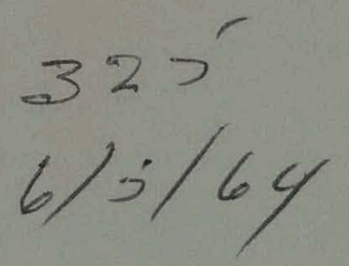

\title{
DECONTAMINATION OF SAVANNAH RIVER WASTE SUPERNATE BY ION EXCHANGE
}

\author{
H. KatZ AND M. ROTHBaRT
}

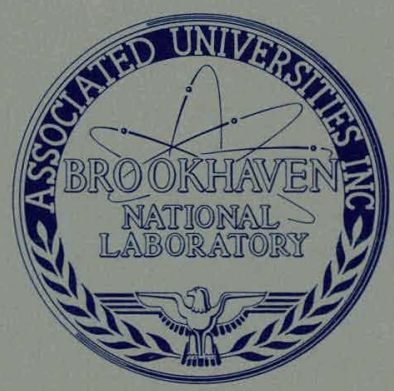

February 1964

BROOKHAVEN NATIONAL LABORATORY

ASSOCIATED UNIVERSITIES, INC. under contract with the

UNITED STATES ATOMIC ENERGY COMMISSION 


\section{DISCLAIMER}

This report was prepared as an account of work sponsored by an agency of the United States Government. Neither the United States Government nor any agency Thereof, nor any of their employees, makes any warranty, express or implied, or assumes any legal liability or responsibility for the accuracy, completeness, or usefulness of any information, apparatus, product, or process disclosed, or represents that its use would not infringe privately owned rights. Reference herein to any specific commercial product, process, or service by trade name, trademark, manufacturer, or otherwise does not necessarily constitute or imply its endorsement, recommendation, or favoring by the United States Government or any agency thereof. The views and opinions of authors expressed herein do not necessarily state or reflect those of the United States Government or any agency thereof. 


\section{DISCLAIMER}

Portions of this document may be illegible in electronic image products. Images are produced from the best available original document. 


\title{
DECONTAMINATION OF SAVANNAH · RIVER WASTE SUPERNATE BY ION EXCHANGE
}

\author{
H. KatZ AND M. ROTHBarT
}

\author{
Written by: H. KaTz \\ M. ROTHBART \\ Work done by: H. KaTZ \\ M. ROTHBART \\ T. SCHREINER
}

February 1964

BROOKHAVEN NATIONAL LABORATORY UPTON, NEW YORK 
This report was prepared as an arcount of rovernment sponsored work. Neqither the United States, nor the Commission, nor any person acting on behalf of the Commission:

A. Makes any warranty or representation, expressed or implied, with respect to the accuracy, completeness, or usefulness of the information contained in this report, or that the use of any information, apparatus, method, or process disclosed in this report may not infringe privately owned rights; or

B. Assumes any liabilities with respect to the use of, or for damages resulting from the use of any information, apparatus, method, or process disclosed in this report.

As used in the above, "person acting on behalf of the Commission" includes any employee or contractor of the Commission, or employee of such contractor, to the extent that such employee or contractor of the Commission, or employee of such contractor prepares, disseminates, or provides access to, any information pursuant to his employment or contract with the Commission, or his employment with such contractor.

\section{PRINTED IN USA}

PRICE 50 CENTS

Available from the

Office of Technical Services

Department of Commerce.

Washington 25, D.C. 
TABLE OF CONTENTS

I. INTRODUCTION. . . . . . . . . . . 1

II. EXPERIMENTAL APPARATUS

AND PROCEDURE . . . . . . . . . . -1

III. TRACER EXPERIMENTS $\ldots \ldots \ldots \ldots \ldots \ldots 2$

A. Clinoptilolite ............. 2

B. Molecular Sieves . . . . . . . . . . . 9

IV. HOT CELL EXPERIMENTS. . . . . . . 13

V. SUMMARY AND CONCLUSIONS . . . . . 16

VI. REFERENCES . . . . . . . . . . . . . . 19 


\section{INTRODUCTION}

This report describes the development of a process for the decontamination of high-level waste supernates by ion exchange: Although a great deal of work along these lines has been reported by Hanford, ${ }^{(1-9)}$ there are differences in the composition of Hanford and Savannah River wastes which seriously affect the performance of the ion exchange materials investigated, and it was the development of a process specifically suitable for Savannah River wastes that constituted the major goal of this work.

A flow sheet has been developed, using Linde AW 400 molecular sieves, which provides effective decontamination of cesium and probably of strontium from highly alkaline waste supernates containing potassium and aluminum. This flow sheet has been demonstrated in hot cell experiments using actual high-level Savannah River waste supernate.

\section{EXPERIMENTAL APPARATUS AND PROCEDURE}

All experiments were conducted using a 1-cm-diam glass column, $40 \mathrm{~cm}$ in height, with a glass frit near the bottom for bed support. Connections to the column were made so that liquid could be pumped upward or downward. Waste solutions were in all cases pumped downward and all other solutions pumped upward. Liquids were pumped with low capacity Lapp Pulsafeeders equipped with flow smoothing devices. Flow rates were measured simply by periodically noting the volume of effluent collected in graduated cylinders.

Except for the actual high-level waste supernate used in the hot cell experiments, all solutions were prepared using reagent grade 
chemicals, and simulated waste solutions were spiked with cesium $\mathbf{- 1 3 7}$ or strontium-85 for analysis by gamma counting.

Clinoptilolite was crushed and screened to the desired size, heattreated where indicated, and soaked in distilled, demineralized water for several days prior to use. Molecular sieves AW 400 or AW 500 (granular ion exchange resins produced by the Linde Company, Tonawonda, New York) were soaked in distilled, demineralized water for at least two weeks prior to use. The ion exchange resins were loaded in the column to a height of about $20 \mathrm{~cm}$ by filling the column with water, attaching a funnel to its top and pouring in a premeasured amount of resin in water. Uniform packing was achieved by vibrating the column while the resin was settling.

\section{TRACER EXPERIMENTS}

\section{A. Clinoptilolite}

The variables studied in connection with the performance of clinoptilolite are effect of heat treatment of the resin, ionic form of the resin, particle size, dilution of the waste, flow rate, and waste composition. Unless otherwise stated, these results were obtained with wastes which did not contain potassium. The composition of the waste used in each case is indicated on the figures.

Three series of duplicate runs were performed in order to study the effect of heat treatment. The duplicate runs were identical in all respects except that in one run of each set the clinoptilolite was heattreated at $400^{\circ} \mathrm{C}$ for $2 \mathrm{hr}$. The results, shown in Figure 1, clearly indicate the improved performance of the heat-treated materlal. 
All of these data were obtained using 30 to 60 -mesh particles, and a flow rate of 8.7 column volumes per hour. The circled points represent the hydrogen form of clinoptilolite, while the other two sets of runs represent the material in its natural form, but with different $\mathrm{pH}$ adjustment of the waste solution. The effect of these variables will be considered later. Based on these results, all subseqquent runs with clinoptilolite used heat-treated material.

The effect of dilution of the waste on column performance is shown in Figure 2. These data were also obtained using 30 to 60 -mesh particles, at a flow rate of 8.8 column volumes per hour. Although the re is some increase in capacity with increasing dilution, it is probably not large enough to justify the increased size of equipment required. Also, Hanford data have shown that at lower flow rates, the effect of dilution becomes negligible. For these reasons, all subsequent work was done at a dilution of $1: 1$.

Since it was suggested that clinoptilolite in the hydrogen form rather than the natural sodium might have a higher cesium capacity, several runs were made using acid-treated clinoptilolite. These runs were made with 30 to 60 -mesh material which was soaked in acid for at least $48 \mathrm{hr}$ prior to use. The waste solutions were adjusted to $\mathrm{pH} 7$ by addition of nitric acid and were fed at a flow rate of 8.9 column volumes per hour. The results, shown in Figure 3, indicate that there is no advantage to using the hydrogen form, at least with high sodium solutions. Several runs were made using the ammonium form, and this performed even worse than the hydrogen form. 

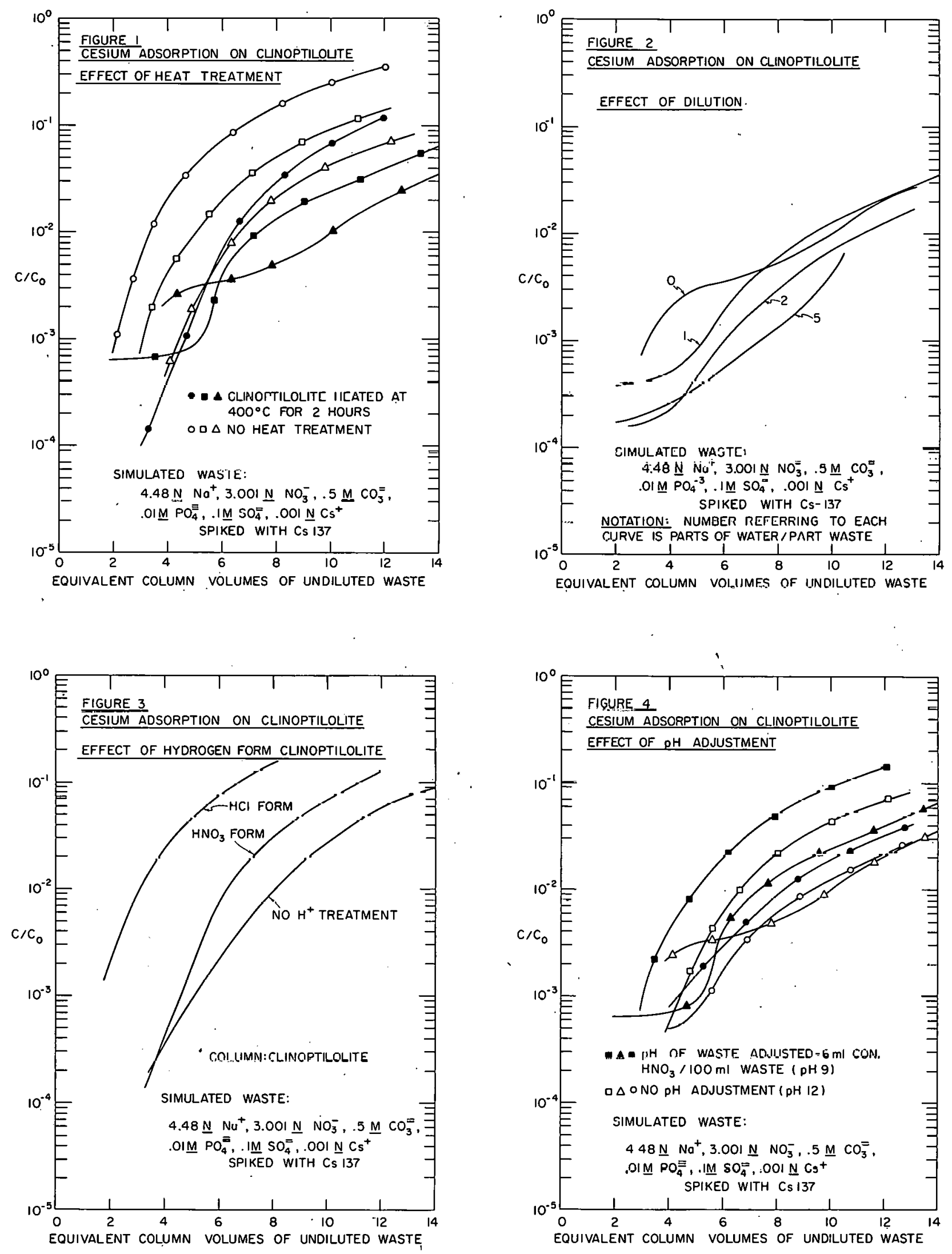
Three sets of duplicate runs were made in which one run of each set used feed adjusted to $\mathrm{pH} 9$ by addition of nitric acid. All these data were obtained using 30 to 60 -mesh particles, and a flow rate of 8.8 column volumes per hour.- The squares represent material used without heat treatment and undiluted waste. The other sets of runs used heattreated material, the triangles representing undiluted waste, and the circles representing waste diluted with an equal volume of water. The results, shown in Figure 4, indicate that lowering the $\mathrm{pH}$ of the feed results in a somewhat lower cesium capacity.

The effects of varying flow rate and particle size on the kinetics of cesium adsorption were studied briefly. These results are shown in Figure 5. These data were obtained using waste diluted with an equal volume of water. It is apparent that decreasing the flow rate results in considerably improved performance, and that decreasing the particle size also results in greatly improved kinetics. Based on all these results, which are in essential agreement with those reported by Hanford, the following operating conditions appear to be optimum: 25 to 50 -mesh particle size, heat-treated for $2 \mathrm{hr}$ at $400^{\circ} \mathrm{C}$, waste diluted $1: 1$, and a flow rate of two column volumes per hour. Unless otherwise indicated, these conditions were used in all subsequent runs, except that molecular seives were not heat treated. Although greatly improved performance would result from the use of finer particles, the possibility of the column plugging would probably prohibit their use.

Some attempts were made to improve the cesium capacity of clinoptilolite by either complexing or precipitating out a portion of the sodium. While it is possible to precipitate 20 to $30 \%$ of the sodium 
with very little loss of cesium, the effect was not large enough to justify - this additional step. As can be seen from the capacity curves shown in Figure 6, it would be necessary to immobilize a much larger fraction of the sodium to achieve a large effect, and this is not feasible.

A typical loading and elution cycle for clinoptilolite under optimum operating conditions is shown in Figure 7. Note that the water rinsing and the acid flush to remove sodium prior to cesium elution both produce effluents which would have to be concentrated and returned to storage tanks. The curve shown was obtained using $0.25 \mathrm{M}$ nitric acid for the flush. Cesium losses increase with increasing acid concentration. The elution was done at room temperature in this run, but according to Hanford data, elution is much more eftect at about $55^{\circ} \mathrm{C}$. Further elution studies with clinoptilolite were not performed because of the availability of data from Hanford, and because other bed materials subsequently looked more promising than clinoptilolite.

The effect of potassium on the performance of clinoptilolite is shown in Figure 8. It is apparent that the presence of $0.04 \mathrm{M}$ potassium results in at least a 50\% more rapid breakthrough. Although the potassium-bearing waste contains slightly more sodium in this case, il was previously established that in this range of sodium concentrations, this vâriation has a negligible effect on the perfurmance of clinuplilolite. It was also previously established that the addition of either aluminum or strontium to the feed had no effect on column performance. The effect of dilution of solutions containing potassium is shown in Figure 8. Again there is a small effect with clinoptilolite, but not sufficient to justify the increased equipment size needed. 

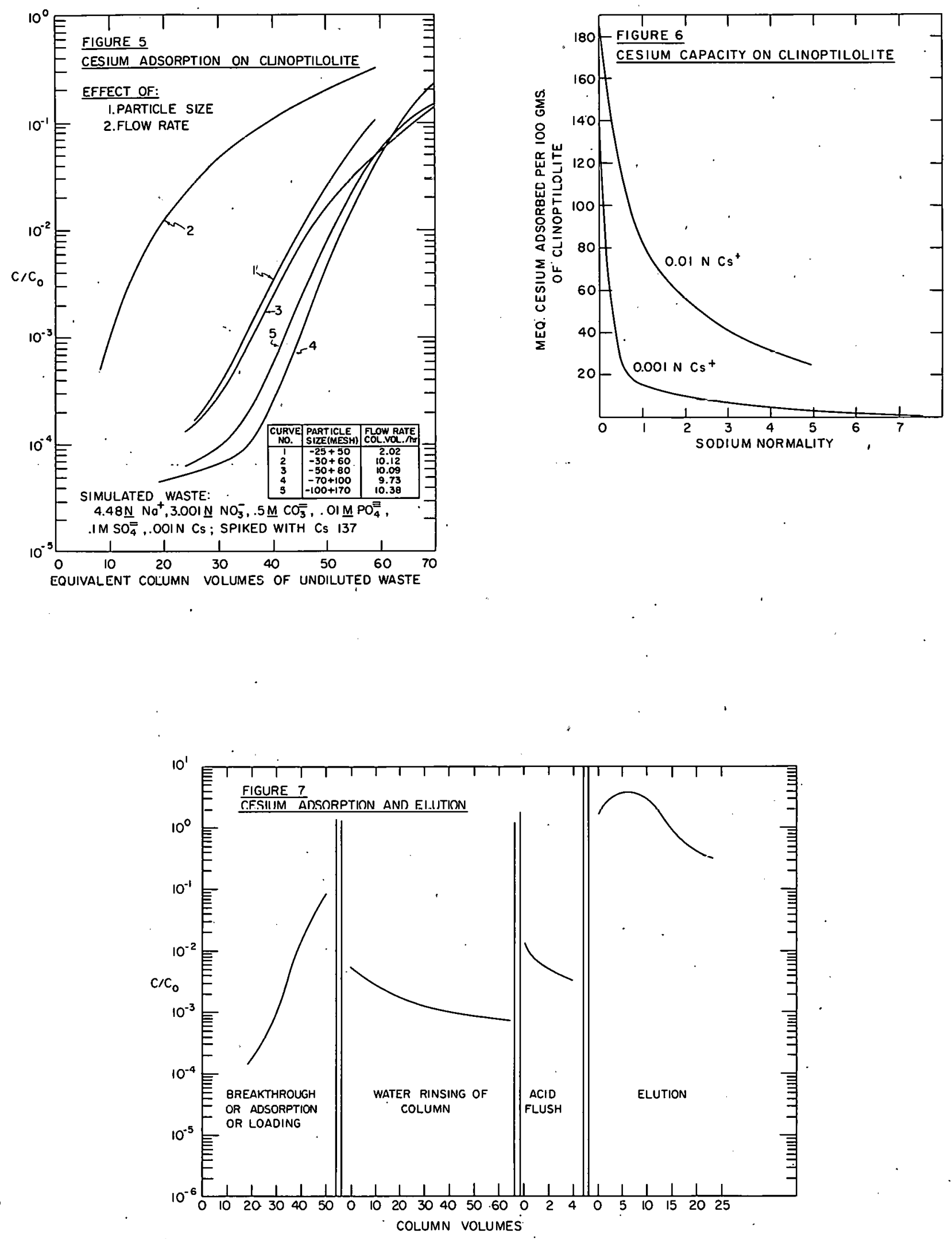

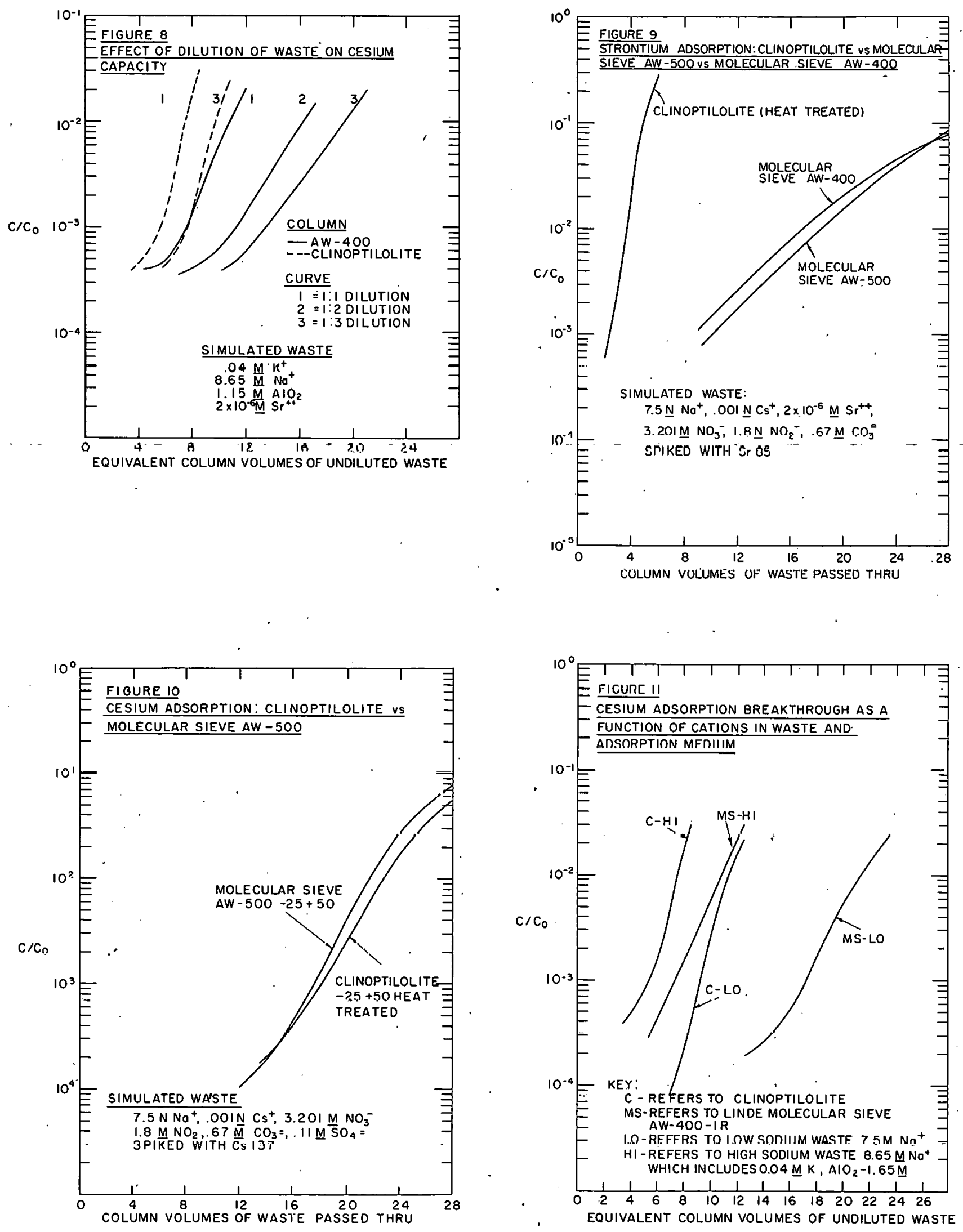
One test was made to determine the ability of clinoptilolite to remove strontium as well as cesium from waste supernates: This result, shown in Figure 9, indicates that negligible decontamination of strontium can be expected with clinoptilolite.

\section{B. Molecular Sieves}

A typical breakthrough for Linde AW 500 molecular sieves is shown in Figure 10. This material does not appear to have any advantage over clinoptilolite, and was not studied extensively since Linde AW 400 molecular sieves proved to be superior to either of the other two materials. Typical breakthrough curves for the latter material are shown in Figure 11, for solutions with and without potassium. Although the presence of potassium has a very deleterious effect on the cesium capacity of this material, its superiority to clinoptilolite is also apparent. The effect of dilution of potassium-containing wastes on the capacity of this material is shown in Figure 8. The capacity of the Linde AW 400 is considerably improved, and dilution, in this case, may be justified, depending on the effluent handling that would be required.

In spite of its superior absorptive properties, two serious problems were encountered in the use of Linde AW 400, but these appear to have been solved. The first problem was due to chemical attack of this material, which resulted in slight crumbling of the sieves during the water wash following the cesium loading. Subsequent investigation indicated that this was due to attack by strong caustic of aluminum oxide either in the adsorbent or in the binder. This was confirmed by the fact that this attack was inhibited when aluminum was added to the waste, presumably due to a mass action effect. A number of runs using 
waste with varying aluminum concentrations showed that between 0.04 and $0.05 \underline{M}$ sodium aluminate is the minimum concentration necessary to inhibit this attack to the point whe re no crumbling was observed with the waste used in these experiments. The concentration of aluminum required would of course depend on the $\mathrm{pH}$ of the waste, but it is felt that the waste used in these experiments was considerably more alkaline than the hot waste obtained from Savannah River, so this concentration of aluminum should be sufficient to prevent crumbling in almost any situation.

The addition of aluminum to the waste, while it was effective in preventing crumbling of the molecular sieves, introduced another problem, which was encountered with the use of cllnuplilulite ag wcll. After the first cycle of loading and elution, a crystalline white precipitate formed in the column on introduction of waste at the start of the secund loading cycle. Although this precipitate eventually redissolved with continued passage of waste through the column, it was voluminous. enough to cause concern over the possibility of the column becoming plugged. Subsequent investigation indicated that the.pH of the liquid left in the column after elution, even following a thorough water rinse, was sufficiently low so that the solubility of sodium aluminate was lowered to the point that it precipitated. As waste was passed through the column, the $\mathrm{pH}$ was raised to the point where this aluminate could be redissolved. This was confirmed when a $1 \mathrm{M} \mathrm{NaOH}$ rinse was introduced following the elution part of the cycle, and this effectively prevented precipitation during the next loading. This treatment, however, resulted in crumbling of the molecular sieves during the water rinse 
$20 \mathrm{CV} / \mathrm{CYCLE}$ TO BE USED AS WASTE DILUENT

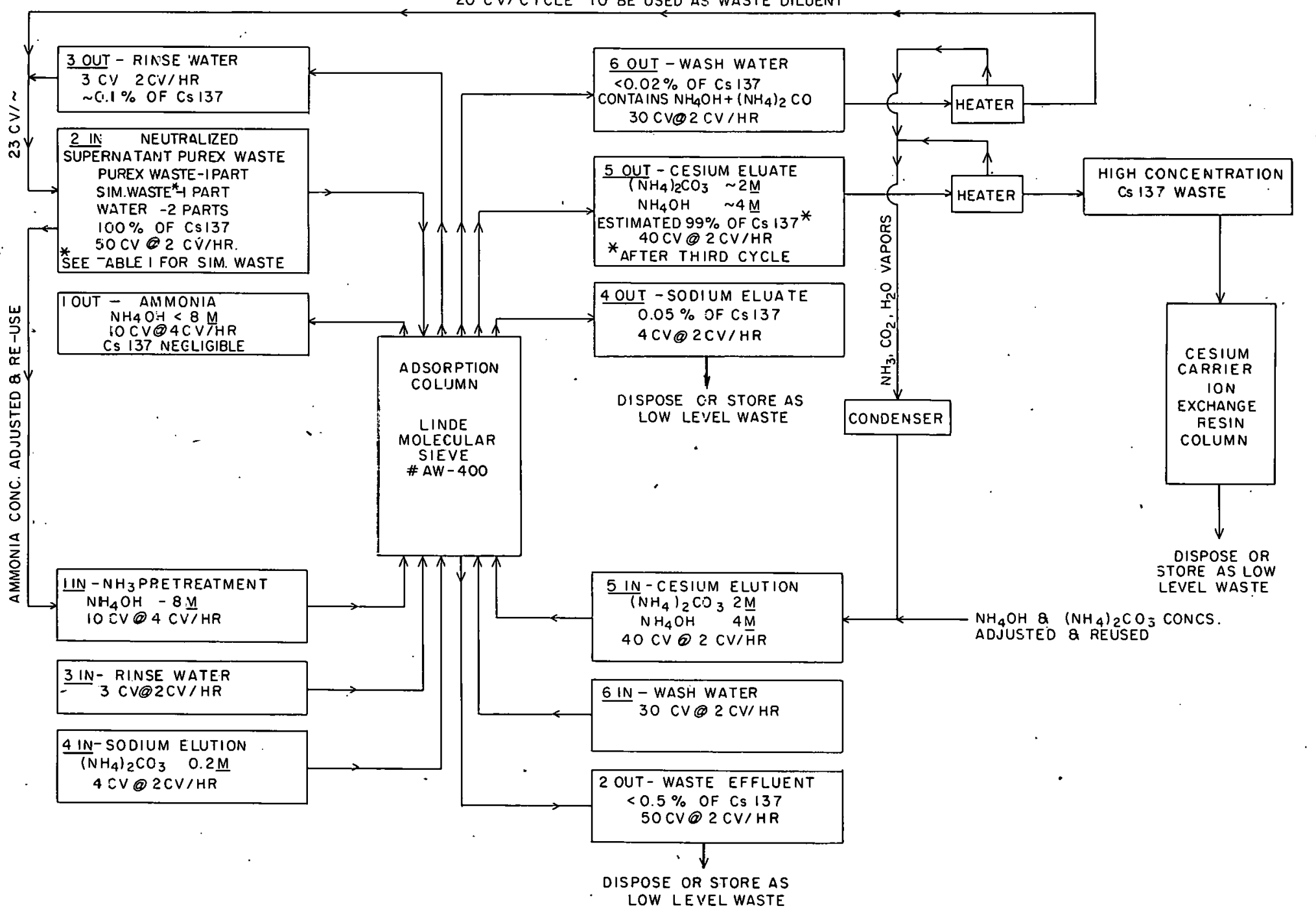

FIGURE 12 PROJECTED FLOW SHEET DECONTAMINATION OF PUREX WASTE SUPERNATE 
following loading. Therefore, an $8 \mathrm{M} \mathrm{NH}_{4} \mathrm{OH}$ was substituted for the $\mathrm{NaOH}$ wash. This was effective in preventing both crumbling and precipitation, and was incorporated into the final flow sheet.

The final flow sheet is illustrated in Figure 12. The procedure for a complete cycle is as follows:

1. Ten column volumes of eight molar ammonium hydroxide are pumped upward through the column at a rate of four column volumes per hour. This is necessary to prevent precipitation on the resin during the waste loading. Since no activity is picked up by this ammonia wash, it can either be discarded or be reused after a concentration adjustment.

2. Waste is passed downward through the column at the rate of two column volumes per hour until $1 \%$ breakthrough. Under the conditions of these experiments, this would occur after the passage of ten to twelve column volumes of actual waste.

3. Three column volumes of water are pumped upward through the column at the rate of two column volumes per hour, to remove the waste remaining in the column. This rinse contains a very slight amount of activity and can be used for dilution of the waste for the next loading cycle.

4. Four column volumes of 0.2 molar ansmunium carbunale dre pumped upward through the column at the rate of two column volumes per hour, to elute the bulk of the sodium from the resin. This effluent contains a slight amount of activity and might be discarded or stored as low-level waste.

5. Forty column volumes of two molar ammonium carbonatefour molar ammonium hydroxide are pumped upward at the rate of two column volumes per hour to elute the cesium. Since the elution was 
allowed to run overnight without sampling; it may be that conside rably less time would actually be required for this step. Also, elutions were performed at room temperature, although Hanford has reported considerably better results at slightly higher temperatures. It should aíso be noted that a small amount of cesium cannot be removed by ammonium carbonate elution. Thus, after the first loading, only about $52 \%$ of the cesium was eluted, after the second loading about $90 \%$ was eluted, and after subsequent loadings essentially all of the additional cesium loaded was eluted. The incomplete elution in the first two cycles has no effect on the capacity of the resin during subsequent loadings.

6. The resin must be thoroughly washed to remove all traces of ammonium carbonate prior to the next loading. This is accomplished by pumping water upward through the column at the rate of two column volumes per hour for fifteen hours. Since this rinse was also allowed to run overnight, the exact volume of rinse required is not known, and may be less than thirty column volumes. This $\mathrm{rinse}$ may be used for dilution of the waste for the next loading, after heating to destroy any residual ammonium carbonate.

In actual practice, several columns in series would probably be used, so that the first column would not be eluted until it was loaded to 80 to $90 \%$ of capacity. Thus considerably more than ten column volumes of waste would be treated by each column before regeneration became necessary.

\section{HOT CELL EXPERIMENTS}

In order to test the proposed flow. sheet under more realistic 
conditions, a number of runs were made in a hot cell using actual highlevel waste supernate obtained from Savannah River. Except for minor changes necessary to facilitate remote manipulation, the equipment and procedures used were essentially the same as those used in cold runs. Because of the small amount of high-level waste available, the waste used in these runs was made up of one part actual waste, one part simulated waste of the same composition, and two parts of water. The flow sheet used is the one just described, except for the difference noted in the first run.

A total of four loadings and three elutions was completed using actual high-level waste supernate. The initial run was preceded by a one molar sodium hydroxide wash, betore it was reallzed that this would cause crumbling of the resin. Because of the crumbling, this resin was discarded after the first loading. However, the results, shown on figur re 13 , provide a direct comparison with a run under identical conditions using simulated waste, shown in Figure 14. This comparison indicates that the re is no significant-difference in behavior between simulated and actual waste under these conditions.

The results of the next set of runs, dune with ammonia pretreatment of the resin, are shown in Figure 15. Although breakthrough is almost twice as rapid in this case, the difference is attributed to the pretreatment of the resin rather than any difference between actual and simulated waste. This suggests that the capacity of the resin may be significantly increased by pretreatment with sodium. hydroxide containing some aluminum, possibly using the effluent from a previous loading but this possibility was not investigated. 

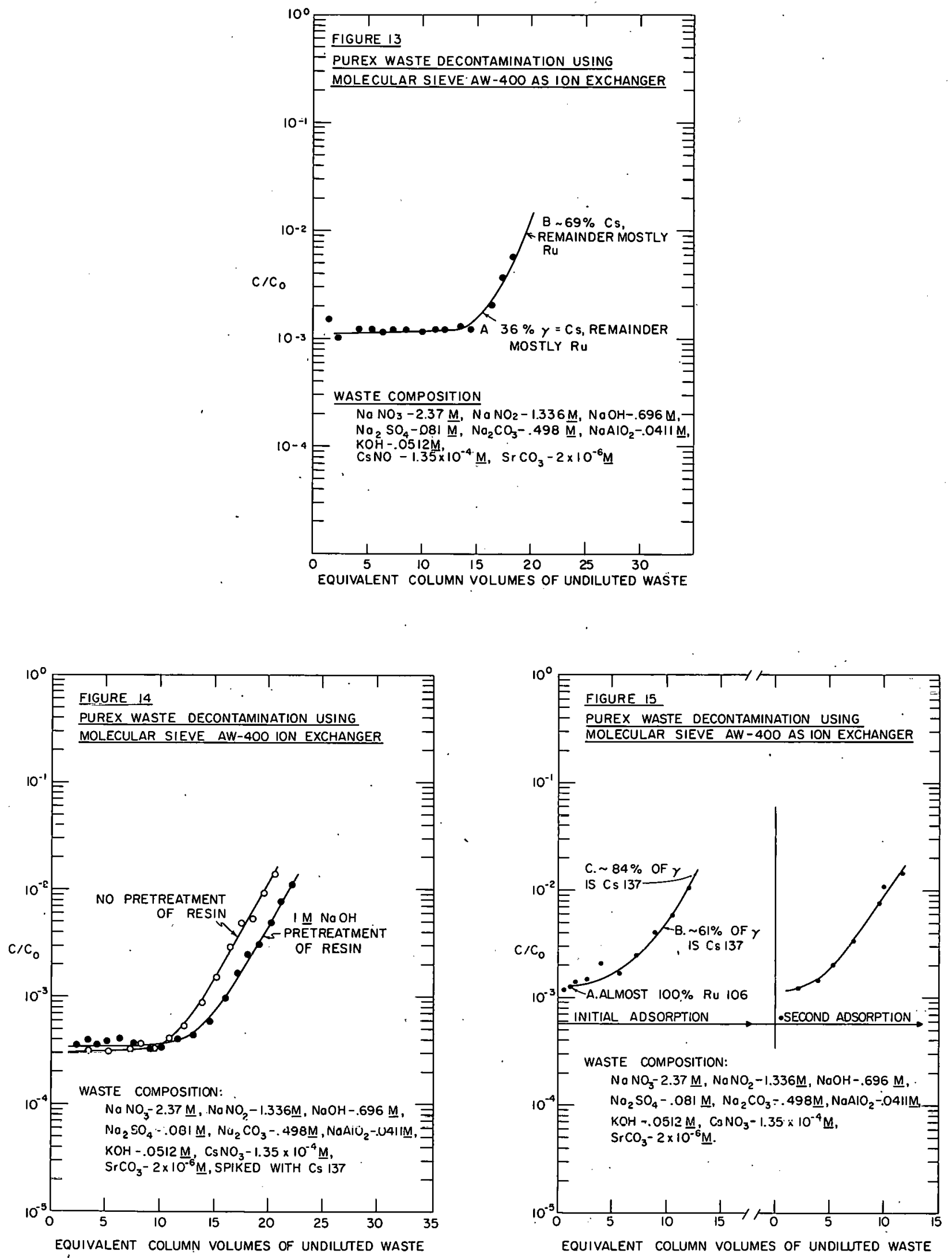
Radiochemical analysis of the effluent at various times showed that initially the gamma activity in the effluent was almost $100 \% \mathrm{Ru}^{106}$, whereas at $1 \%$ breakthrough the activity in the effluent was $84 \% \mathrm{Cs}^{137}$, the remainder being mainly $\mathrm{Ru}^{106}$. Strontium was not detected either in the feed or effluent samples, indicating that if there were traces of it in the waste, it was completely adsorbed. An activity balance for two complete cycles is shown in Table 1.

\section{SUMMARY AND CONCLUSIONS}

1. A flow sheet has been developed for the decontamination of Savannah River waste supernate by ion exchange, using Linde AW 400 molecular sieves. Satisfactory decontamination from cesium and strontium can be achieved with this material, the activity in the effluent being mainly $\mathrm{Ru}^{106}$.

2. The presence of potassium in the waste seriously decreases the cesium capacity of all ion exchange materials studied. Linde AW 400 molecular sieve is the only material investigated having sufficient capacity in the presence of 0.05 molar potassium to be of practical consideration. The cesium capacity is not affected by the ionic composition of the waste except for sodium and potassium.

3. In order to prevent chemical attack of Linde AW 400 molecular sieve by highly alkaline wastes, sodium aluminate must be added to the waste to a concentration of at least 0.04 molar. In order to prevent precipitation of sodium aluminate on the resin after the elution portion of the cycle, all dunumia linse is necessary prior to the introduction of fresh waste. 
Table 1

Purex Waste Decontamination - Inventory

Repetitive Run - Column Ammonia Pretreated

Waste - 1 part Purex: 1 part simulated: 2 parts water

Inventory of all $\gamma$ counts

1st adsorption feed, $475.2 \mathrm{ml}$ at $2.535 \times 10^{8} \gamma$ counts $/ \mathrm{min} / \mathrm{ml}$

$$
=1204.6 \times 10^{8} \text { PASSED THROUGH }
$$

Not adsorbed

99. $2 \%$ adsorption $\frac{-9.4}{1195.2}$

REMAINING

$50 \mathrm{ml} \mathrm{H}_{2} \mathrm{O}$ rinse

$\frac{-3.5}{1191.7}$

REMAINING

$70 \mathrm{ml} \mathrm{Na}$ elution

$\left[0.2 \underline{\mathrm{M}}\left(\mathrm{NH}_{4}\right)_{2} \mathrm{CO}_{3}\right]$

$$
\frac{-0.5}{1191.2}
$$

REMAINING

Cs elution

$2 \mathrm{M}\left(\mathrm{NH}_{4}\right)_{2} \mathrm{CO}_{3} \cdot 4 \mathrm{NH}_{4} \mathrm{OH} \frac{-618.4}{572.8} \times 10^{8}$ REMAINING

$51.9 \%$ elution

overnight $\mathrm{H}_{2} \mathrm{O}$ wash

$$
\frac{-0.2}{572.6} \times 10^{8} \text { REMAINING }
$$

$8 \mathrm{M} \mathrm{NH}_{4} \mathrm{OH}$ pretreatment for 2nd run

No $\gamma$ drive off

2nd adsorption feed,

$416.5 \mathrm{ml}$ at $2.536 \times 10^{8}=1055.8 \times 10^{8}$ PASSED THROUGH

Total on column

$=1628.4 \times 10^{8}$

Not adsorbed

99.5\% adsorption

$\frac{-4.9}{1623.5}$

REMAINING

$50 \mathrm{mI} \mathrm{H}_{2} \mathrm{O}$ rinse

$\frac{-0.5}{1623.0}$

$70 \mathrm{ml} \mathrm{Na}$ elution

$\frac{-0.6}{1622.4}$

REMAINING

Cs elution

$\frac{-941.1}{681.3}$

REMAINING

681.3

REMAINING

$90.6 \%$ of Second Loading - Eluted 
4. The proposed flow sheet has been demonstrated both with simulated waste on a tracer level and with actual high-level waste supernate in hot cell experiments. Results indicate no difference in behavior between simulated and actual waste solutions. 


\section{RE FERENCES}

1. HW 65209, Quarterly Progress Report for Research and Development Activities, Fixation of Radioactive Residues, D. W. Pearce, ed., Jan.Mar. 1960.

2. HW 66571, Quarterly Progress Report for Research and Development Activities, Fixation of Radioactive Residues, D. W. Pearce, ed., AprilJune 1960.

3. HW 67334, Quarterly Progress Report for Research and Development Activities, Fixation of Radioactive Residues, D. W. Pearce, ed., JulySept. 1960.

4. HW 69176, Quarterly Progress Report for Research and Development Activities, Fixation of Radioactive Residues, D. W. Pearce, ed., Jan.Mar. 1961.

5. HW 70517, Quarterly Progress Report for Research and Development Activities, Fixation of Radioactive Residues, E. R. Irish, ed., AprilJune 1961.

6. HW 71374, Quarterly Progress Report for Research and Development Activities, Fixation of Radioactive Residues, E. R. Irish, ed., JulySept. 1961.

7. HW 73412, Quarterly Progress Report for Research and Development Activities, Fixation of Radioactive Residues, E. R. Irish, ed., Jan. Mar. 1962.

8. HW 74375, Quarterly Progress Report for Research and Development Activities, Fixation of Radioactive Residues, E. R. Irish, ed., Apr.June 1962.

9. HW 75290, Quarterly Progress Report for Research and Development Activities, Fixation of Radioactive Residues, E. R. Irish, ed., JulySept. 1962. 